\title{
Neurotrophins and neurotransmitters in human palatine tonsils: An immunohistochemical and RT-PCR analysis
}

\author{
ELENA BRONZETTI ${ }^{1}$, MARCO ARTICO $^{2}$, ELENA POMPILI ${ }^{1}$, LAURA M. FELICI $^{1}$, \\ ANNARITA STRINGARO ${ }^{5}$, SANDRO BOSCO ${ }^{3}$, GIUSEPPE MAGLIULO $^{4}$, MARISA COLONE ${ }^{5}$, \\ GIUSEPPE ARANCIA $^{5}$, MARCO VITALE ${ }^{6,7}$ and LORENZO FUMAGALLI ${ }^{1}$
}

\begin{abstract}
${ }^{1}$ Department of Cardiovascular, Respiratory and Morphological Sciences, University of Rome La Sapienza, Via A. Borelli 50-00161; ${ }^{2}$ Department of Human Physiology and Pharmacology; ${ }^{3}$ Service of Pediatric Histology; ${ }^{4}$ G. Ferreri Department of Otorhinolaryngology, Audiology and Phoniatry, University of Rome 'La Sapienza', P.le A. Moro 5-00185; ${ }^{5}$ Department of Technology and Health of the Italian National Institute of Health, V.le Regina Elena 299-00161, Rome; ${ }^{6}$ Department of Human Anatomy, Pharmacology \& Forensic Medicine, University of Parma, Via Gramsci 14, Parma; ${ }^{7}$ Institute of Cytomorphology NP-CNR-c/o Res. Institute ‘Codivilla-Putti', Via di Barbiano 1/10, Bologna, Italy
\end{abstract}

Received February 1, 2006; Accepted March 27, 2006

\begin{abstract}
Lymphoid organs are supplied by many nerve endings associated with different kinds of cells and macrophages. The role of these neuromediators on the release of locally active molecules is still unknown. Here we focused our attention on the expression of some neurotrophins (NTs), their high- and low-affinity receptors and several neurotransmitters in human palatine tonsils. Light and electron microscopy immunohistochemistry showed that human tonsillar samples were positive for all analyzed neurotrophins (NGF, BDNF and NT-3) and their high-affinity receptors (TrkA, TrkB and TrkC, respectively). All of these molecules were strongly expressed in macrophages whereas, in some patients, a weaker specific staining of lymphocytes and blood vessels was also found. The low-affinity receptor for NGF (p75) was always absent in the analysed samples. RT-PCR confirmed the occurrence of specific transcripts for NTs and their high-affinity receptors as well as the absence of mRNA for p75 protein. Also, specific immunoreactivity for neurotransmitters SP, VIP, CGRP, ChAT and nNOS was mainly expressed by macrophagic cells. These results suggest the presence of an extensive network of innervation in the human palatine tonsils which may play a role in the regulation of some immune functions as well as in the modulation of a
\end{abstract}

Correspondence to: Professor Elena Bronzetti, Department of Cardiovascular, Respiratory and Morphological Sciences, University of Rome 'La Sapienza', Via Alfonso Borelli 50, 00161 Rome, Italy

E-mail: elena.bronzetti@uniroma1.it

Key words: human tonsil, immunohistochemistry, neurotrophins, nNOS, SP, VIP, CGRP, cholinacetyltransferase, electron microscopy possible functional scenario of interactions among different immune cellular subtypes.

\section{Introduction}

The nervous and the immune systems are functionally related and human mucosae lymphoid tissue are considerably innervated (1). Mucosae-associated lymphoid tissue, particularly the tonsils, are in contact with the external environment and are known to contain numerous lymphocytes and macrophages which defend the host against pathogens. As a part of the immune system, the tonsils are supposed to interact with the nervous system by an extensive network, involving many signaling molecules. Regarding this connection, information is still scarce about neurotrophin expression and innervation of the human tonsils. Neurotrophins (NTs), also known as neurotrophic factors, constitute a family of dimeric proteins working as polypeptidic growth factors, which include nerve growth factor (NGF), brain derived growth factor (BDNF), neurotrophin-3 (NT-3), NT-4/5 and NT-6, the last being apparently specific for fish (2). Biological actions of NTs are mediated by the binding with two families of membrane receptors, the high-affinity tyrosine kinase (Trk) and the lowaffinity p75 (p75NT receptor) receptors $(3,4)$. The Trk family includes TrkA, TrkB and TrkC receptors, whereas the p75NT receptor belongs to the trans-membrane molecules serving as receptor for tumor necrosis factor and cytokines (4). TrkA is specifically activated by NGF, whereas TrkB and TrkC are primarily receptors for BDNF and NT-3 respectively $(5,6)$. NTs are involved in vertebrate neuronal cell development, differentiation, survival and functional activities $(2,7)$. NTs are also involved in the modulation of adult central nervous system functions and organization, as well as in the vegetative innervation of several organs (5,7-12). Moreover, detailed studies have revealed significant actions of neurotrophins in a wide variety of tissues outside the nervous system, especially in the immune system (13-17). In 
particular, it is supposed that immune tissue is capable of concentrating NGF, which in turn may modulate the level of innervation by the sympathetic nervous system (18-21).

In order to gain information about this matter, we studied the innervation and the expression of NTs and their receptors in different cellular subtypes (lymphocytes, macrophages and epithelial cells) of human palatine tonsils to investigate a possible relationship between functional and physiopathological mechanisms.

\section{Materials and methods}

Clinical material. Human tonsil tissue was surgically removed from seven patients and subjected to immunohistochemical and RT-PCR analysis. Experiments were performed in compliance with the Italian laws and guidelines concerning the informed consent of the patients.

Immunohistochemical analysis by light microscopy. The following molecules were investigated: nerve growth factor (NGF), brain derived neurotrophic factor (BDNF), neurotrophin 3 (NT-3), tyrosine kinase A (TrkA), tyrosine kinase B (TrkB), tyrosine kinase C (TrkC), protein 75 (p75), substance P (SP), vasointestinal peptide (VIP), calcitonin gene-related peptide (CGRP), choline acetyltransferase (ChAT) and neuronal nitric oxide synthase (nNOS).

For light microscope immunohistochemical analysis, small fragments of tonsil tissue were washed in PBS, fixed in $10 \%$ formalin and embedded in paraffin according to a standard procedure. Serial $10-\mu \mathrm{m}$ thick sections were cut using a rotatory microtome, mounted on gelatin-coated slides and processed for immunohistochemistry. To study the immunolocalization of neurotrophins and their receptors, the antibodies we used were: rabbit anti-NGF polyclonal antibody (Santa Cruz, CA, USA), which displayed less than $1 \%$ cross-reactivity against recombinant human NT-3, NT-4 and BDNF; rabbit anti-BDNF polyclonal antibody (Santa Cruz), which recognized the amino-terminus of mouse BDNF and did not cross-react with NT-3 or NGF; rabbit anti-NT-3 polyclonal antibody (Santa Cruz), which was raised against the amino-terminus of mouse NT-3 and did not cross-react with NGF or BDNF; rabbit anti-TrkA polyclonal antibody (Santa Cruz) which recognized an epitope correspond-ing to aminoacids 763 to 777 , mapping adjacent to the carboxy terminus of human TrkA p140 and was not cross reactive with TrkB or TrkC; rabbit anti-TrkB polyclonal antibody (Santa Cruz), which recognized an epitope corresponding to aminoacids 794 to 808 of mouse TrkB p145 and was not cross- reactive with TrkA or TrkC; rabbit antiTrkC polyclonal antibody (Santa Cruz), which recognized an epitope corresponding to aminoacids 798 to 812 of porcine TrkC p140 and was not cross-reactive with TrkA or TrkB; and goat polyclonal antibody to human NGF receptor p75 (Santa Cruz), which recognized the amino acid sequence mapping the carboxy terminus of the NGF receptor p75 precursor of human origin and was not cross-reactive with other growth factor receptors. For analysis of neurotransmitters, the following antibodies were used: rabbit antiSP polyclonal antibody (Chemicon International, CA, USA); rabbit anti-VIP polyclonal antibody (Chemicon International); mouse anti-CGRP monoclonal antibody (Chemicon International); goat anti-ChAT polyclonal antibody (Chemicon International); and rabbit anti-nNOS polyclonal antibody (Chemicon International). The immunohistochemical recognition of macrophages was performed by a mouse antihuman CD68 monoclonal antibody (DakoCytomation, Denmark) whereas the immunohisto-chemical recognition of lymphocytes was performed by a mouse anti-CD38 monoclonal antibody (Santa Cruz). Incubation with primary antibodies was performed overnight at $4^{\circ} \mathrm{C}$ at a final concentration of $2-5 \mu \mathrm{g} / \mathrm{ml}$. Optimal antisera dilutions and incubation times were assessed in a series of preliminary experiments. After exposure to the primary antibodies, slides were rinsed twice in phosphate buffer and incubated $(1 \mathrm{~h}$ and $30 \mathrm{~min}$ at room temperature) with the appropriate secondary antibody conjugated to horseradish peroxidase (HRP) (final dilution 1:100). The secondary antibody-HRP linked against rabbit immuno-globulins was purchased from Boehringer (Boehringer Mannheim GmbH, Mannheim, Germany), while secondary antibodies-HRP linked against mouse and goat immuno-globulins were from Sigma (Sigma Chemicals Co, St Louis, MO, USA). After a further wash with phosphate buffer, slides were treated with $0.05 \%$ 3,3-diaminobenzidine and $0.1 \% \mathrm{H}_{2} \mathrm{O}_{2}$. Finally, sections were counterstained with Mayer's hematoxylin and observed by using a light microscope. To block endogenous peroxidase activity, slides were pretreated with $3 \% \mathrm{H}_{2} \mathrm{O}_{2}$, whereas the non-specific binding of immunoglobulins was prevented by adding $3 \%$ fetal calf serum to the incubation medium. Negative control experiments were performed: by omitting the primary antibody; by substituting the primary antibody with an equivalent amount of nonspecific immunoglobulins; by pre-incubating the primary antibody with the specific blocking peptide (antigen/antibody $=5$ according to manufacturer's instructions). In preliminary experiments, immunohisto-chemistry was performed also on frozen sections of human tonsil tissue. We found no differences in the intensity or distribution of immunostaining using the two types of sections, but we preferred paraffin-embedded material because microanatomical details were better preserved. The intensity of immune reaction was assessed microdensitometrically by an IAS 2000 image analyzer (Delta Sistemi, Rome, Italy) connected via a TV camera to the microscope. The system was calibrated taking as zero the background obtained in sections exposed to non-immune serum. Ten $100 \mu \mathrm{m}^{2}$ areas were delineated in each section by a measuring diaphragm. Quantitative data of the intensity of the immune staining were analyzed statistically by analysis of variance (ANOVA) followed by Duncan's multiple range test as a post hoc test.

Immunolabeling by electron microscopy. Tonsillar samples were cut into small pieces $\left(1-2 \mathrm{~mm}^{3}\right)$, fixed with $4 \%$ paraformaldehyde plus $0.1 \%$ glutaraldehyde in PBS, pH 7.4, for $2 \mathrm{~h}$ at $4^{\circ} \mathrm{C}$, washed in PBS and then infiltrated with $2.3 \mathrm{M}$ sucrose in PBS for $3 \mathrm{~h}$ at $4^{\circ} \mathrm{C}$, frozen in liquid nitrogen, and cryosectioned following the method by Tokuyasu (22). Ultrathin cryosections, obtained by using a Leica Ultracut UCT device (Leica Microsystem, Wien, Austria), were collected using sucrose and methylcellulose and incubated overnight at $4{ }^{\circ} \mathrm{C}$ with the specific primary antibodies and 
Table I. Results of the immunohistochemical analysis performed on the tonsil tissue of 7 patients for NTs, NT receptors and neurotransmitters. ++ , strong immunoreactivity; +, moderate immunoreactivity; \pm , weak immunoreactivity; -, absence of immunoreactivity.

\begin{tabular}{|c|c|c|c|c|c|c|c|c|}
\hline & $\begin{array}{c}\text { Expressing } \\
\text { Cells }\end{array}$ & Pat 1 & Pat 2 & Pat 3 & Pat 4 & Pat 5 & Pat 6 & Pat 7 \\
\hline \multirow[t]{2}{*}{ NGF } & Macrophages & ++ & ++ & + & ++ & + & ++ & ++ \\
\hline & Lymphocytes & + & + & \pm & + & + & \pm & + \\
\hline \multirow[t]{2}{*}{ BDNF } & Macrophages & + & ++ & + & + & ++ & + & + \\
\hline & Lymphocytes & + & + & + & \pm & + & + & \pm \\
\hline \multirow[t]{3}{*}{ NT3 } & Macrophages & ++ & ++ & ++ & + & ++ & ++ & + \\
\hline & Lymphocytes & \pm & \pm & - & \pm & \pm & \pm & - \\
\hline & Blood vessels & + & + & + & + & + & + & + \\
\hline \multirow[t]{3}{*}{ TrkA } & Macrophages & ++ & ++ & ++ & + & ++ & + & ++ \\
\hline & Lymphocytes & + & + & \pm & \pm & + & \pm & \pm \\
\hline & Blood vessels & \pm & + & \pm & \pm & + & \pm & \pm \\
\hline \multirow[t]{3}{*}{ TrkB } & Macrophages & ++ & ++ & + & + & ++ & ++ & ++ \\
\hline & Lymphocytes & ++ & +++ & ++ & ++ & +++ & +++ & +++ \\
\hline & Blood vessels & + & + & + & + & + & + & + \\
\hline \multirow[t]{2}{*}{ TrkC } & Macrophages & ++ & + & ++ & ++ & ++ & + & ++ \\
\hline & Lymphocytes & - & \pm & \pm & \pm & \pm & \pm & - \\
\hline \multicolumn{2}{|l|}{ p75 } & - & - & - & - & - & - & - \\
\hline \multirow[t]{2}{*}{ SP } & Macrophages & ++ & ++ & ++ & ++ & ++ & ++ & ++ \\
\hline & Lymphocytes & \pm & \pm & \pm & - & \pm & \pm & \pm \\
\hline \multirow[t]{3}{*}{ VIP } & Macrophages & ++ & ++ & ++ & + & ++ & ++ & ++ \\
\hline & Lymphocytes & \pm & + & + & \pm & + & \pm & + \\
\hline & Blood vessels & + & + & + & + & + & + & + \\
\hline \multirow[t]{2}{*}{ CGRP } & Macrophages & ++ & ++ & ++ & +++ & ++ & ++ & +++ \\
\hline & Lymphocytes & \pm & - & - & - & \pm & - & - \\
\hline \multirow[t]{2}{*}{ ChAT } & Macrophages & - & \pm & \pm & + & + & \pm & \pm \\
\hline & Lymphocytes & ++ & ++ & + & ++ & ++ & + & ++ \\
\hline \multirow[t]{3}{*}{ nNOS } & Macrophages & + & \pm & + & \pm & + & \pm & + \\
\hline & Lymphocytes & + & + & + & + & + & + & + \\
\hline & Blood vessels & + & \pm & + & \pm & + & + & + \\
\hline
\end{tabular}

then with goat anti-mouse or anti-rabbit immunoglobulins 5and 10-nm gold conjugated (Sigma-Aldrich, Milan, Italy). Control samples were obtained by omitting the incubation with the specific primary antibody. Finally, ultrathin cryosections were stained with a $2 \%$ methylcellulose and $0.4 \%$ uranyl acetate solution. Samples were examined with a Philips 208 transmission electron microscope (FEI Company, Eindhoven, The Netherlands).

$R T-P C R$. Total RNA was isolated from human tonsil tissue by using TRIzol reagent (Invitrogen, Carlsbad, CA, USA) according to manufacturer's instructions. cDNA was synthesized from $1 \mu \mathrm{g}$ total RNA in a final reaction volume of $20 \mu 1$. Briefly, a mixture of total RNA, oligo (dT), dNTP mix and DEPC-treated distilled water was pre-incubated for $5 \mathrm{~min}$ at $65^{\circ} \mathrm{C}$; then SuperScript III reverse transcriptase (200U), RNase ribonuclease inhibitor, DTT and buffer $(250 \mathrm{mM}$ Tris
$\mathrm{pH} 8.3,375 \mathrm{mM} \mathrm{KCl}, 15 \mathrm{mM} \mathrm{MgCl}_{2}$ ) were added to the mixture and incubation was continued for $45 \mathrm{~min}$ at $50^{\circ} \mathrm{C}$. Finally, Superscript III was inactivated by heating for $15 \mathrm{~min}$ at $70^{\circ} \mathrm{C}$. All reagents were from Invitrogen. Of the resulting cDNA, 3-5 $\mu 1$ were amplified by polymerase chain reaction (PCR). Each PCR tube contained the following reagents: $0.2 \mu \mathrm{M}$ of both sense and antisense primers, 3 to $5 \mu 1$ template cDNA, 0.2 mM 4-dNTP mix (Invitrogen), 2.5 U Platinum TaqDNA polymerase (Invitrogen) and $1 \mathrm{X}$ reaction buffer (Invitrogen). $\mathrm{MgCl}_{2}$ was added at a final concentration of $1 \mathrm{mM}$ for BDNF, NT-3, TrkA and TrkB and at a final concentration of $1.5 \mathrm{mM}$ for NGF, TrkC and $\mathrm{p} 75$. The final volume was 50 $\mu 1$. The PCR primers used for amplifying neurothrophins and their receptors (M-Medical, Florence, Italy) were as follows: for NGF, forward TCATCATCCCATCCCATCTT, reverse CTTGACAAAGGTGTGAGTCG; for BDNF, forward AGCCTCCTCTGCTCTTTCTGCTGGA, reverse CTTTT 


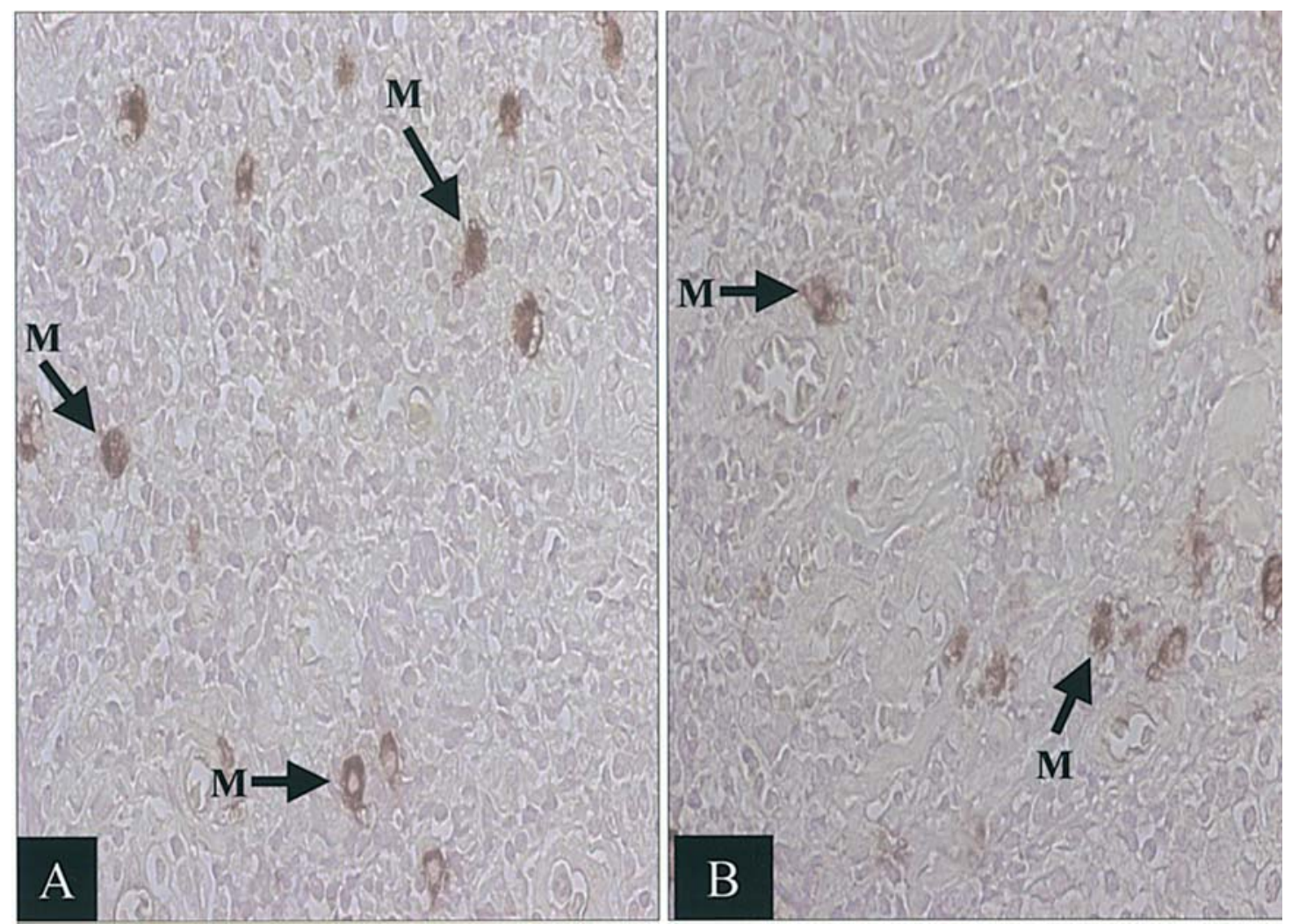

Figure 1. Human tonsil tissue: patient no. 5. Micrographs of NGF (A) and Trk-A (B) immunostaining. Strong immunoreactivity for NGF and its specific receptor, TrkA, is observed in macrophagic cells (M) whereas lymphocytes and blood vessel endothelium are weakly stained.
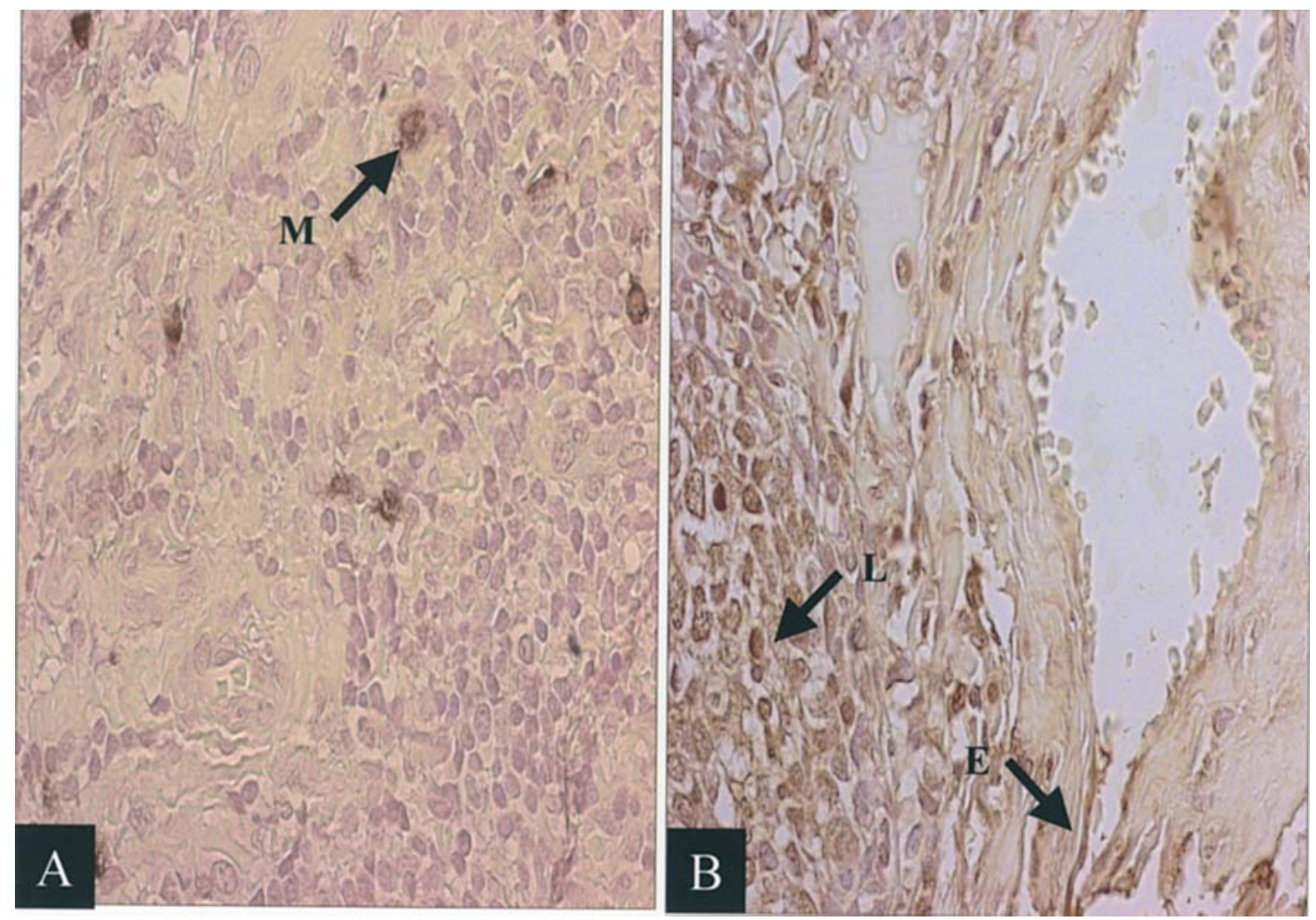

Figure 2. Human tonsil tissue: patient no. 1. Micrographs of BDNF (A) and TrkB (C) immunostaining. Strong immunoreactivity for BDNF is associated to macrophages (M) whereas (B) its specific receptor, TrkB, is strongly expressed by lymphocytes (L). Weak immunostaining for TrkB is also observed in macrophages and blood vessel endothelium (E). 
GTCTATGCCCCTGCAGCCTT; for NT-3, forward TTTCTCGCTTATCTCCGTGGCATCC, reverse GGCAGG GTGCTCTGGTAATTTTCCT; for TrkA, forward TCTT CACTGAGTTCCTGGAG, reverse TTCTCCACCGG GTCTCCAGA; for TrkB, forward AAGACCCTGAAGG ATGCCAG, reverse AGTAGTCAGTGCTGTACACG; for TrkC, forward GGAAAGGTCTTCCTGGCCGAGTGC, reverse GCTTTCCATAGGTGAAGATCTCCC; for p75, forward TGGACAGCGTGACGTTCTCC, reverse GATCT CCTCGCACTCGGCGT. The specificity of the primers was verified by searching the NCBI database for every possible homology to cDNAs of unrelated known proteins. The PCR reaction consisted of incubation for $2 \mathrm{~min}$ at $94^{\circ} \mathrm{C}$ followed by $30-35$ cycles of incubation at $94^{\circ} \mathrm{C}$ for $30 \mathrm{sec}, 56^{\circ} \mathrm{C}$ (for NGF, TrkA and TrkB) or $62^{\circ} \mathrm{C}$ (for BDNF, NT-3, p75 and TrkC) for $30 \mathrm{sec}$ and $72^{\circ} \mathrm{C}$ for $1 \mathrm{~min}$. PCR products were separated by agarose gel electrophoresis (Submarine agarose gel unit; Hoefer, San Francisco, CA, USA) and visualized using a digital gel documentation system (GelDoc 2000 System/QuantityOne software; Bio-Rad Laboratories, Hercules, CA, USA).

\section{Results}

Light microscopy immunohistochemistry. Sections of tonsil samples exposed to primary/secondary antibodies developed a dark-brown (intense), yellow-brown (slight) or no immunostaining. Immunoreactivity was specific, since no immunostaining was obtained in control sections incubated with each primary antibody adsorbed with the specific peptide or with pre-immune serum (not shown). Immunolabeling was located in the macrophages, lymphocytes and blood vessels of tonsil tissue (Table I).

Strong immunoreactivity for NGF was observed in macrophage cells and moderate immunoreactivity was found in lymphocytes of all patients (Fig. 1A). Immunoreactivity for BDNF was well expressed in macrophage cells of all patients; lymphocytes showed a moderate staining (Fig. 2A). Strong immunoreactivity for NT-3 was observed in the macrophages of all patients and slight immunoreactivity was detected in the lymphocytes of five out seven analyzed patients; moderate immunoreactivity was present in the blood vessels (Fig. 3A). Strong immunoreactivity for TrkA receptor was detected in the macrophages and weak reaction was evident in the lymphocytes and blood vessels of all patients (Fig. 1B). Appreciable immunoreactivity for TrkB receptor was detected in the macrophages while strong expression was evident in the lymphocytes of all patients; blood vessels showed weak immunoreactivity (Fig. 2B). Strong expression of TrkC was relevated in macrophages of all patients and weak immunoreactivity was detected in the lymphocytes of five out of seven analyzed patients (Fig. 3B). No expression of $\mathrm{p} 75$ was relevated in anyone of the seven analyzed patients (not shown). Strong immunoreactivity for SP was detected in the macrophages and weak positivity was observed in the lymphocytes of all analyzed patients (Fig. 4A). Immunoreactivity for VIP was strong in macrophages, weak in lymphocytes and moderate in blood vessels of all patients (Fig. 4B). Strong immunoreactivity for CGRP was evident in the macrophages of all patients; lymphocytes were only weakly labelled in two out of seven analyzed patients (Fig. 4C).
Weak expression for ChAT was detected in the macrophages while strong immunoreactivity was detected in the lymphocytes of all analyzed patients (Fig. 4D). Weak immunoreactivity for nNOS was detected in the macrophages while expression was moderate in lymphocytes and blood vessels of all analyzed patients (Fig. 5).

The results obtained are summarized in Table I. It can be observed that macrophages stained for all of the markers analyzed with the exception of p75. On the contrary, lymphoid cells and vascular endothelial cells showed a variable expression of the different markers, although, in general, not as strong as macrophages.

ImmunoTEM. The observation by transmission electron microscopy of cryosectioned human tonsillar samples revealed a relatively good morphological preservation. Fig. 6C showed a portion of a control unlabeled cryosection in which a macrophagic cell with indented nucleus, a fibroblastic cell with elongated nucleus and, adjacent to a cross-sectioned bundle of collagene, a capillary vessel surrounded by endothelial cells were visible.

When the same sections were labelled with anti-NGF antibody, an intense positivity was revealed in macrophages (Fig. 6A). Fig. 6A shows numerous gold particles randomly distributed inside the cytoplasm whereas the nucleus appears to be completely negative. Macrophages were positive also for BDNF (not shown) and NT-3 (not shown) and the receptors, TrkA (Fig. 6B), TrkB (not shown) and TrkC (not shown). Lymphocytes were stained with all analyzed markers, but they were particularly reactive with anti-TrkB antibody (Fig. 7B). In TrkB-labelled samples, numerous clusters of gold particles were observed inside the cytoplasmic matrix and associated to plasma membrane (Fig. 7B). Labelling of the tonsillar samples with anti-CD38 mAb demonstrated that the observed cells were indeed lymphocytes since they showed numerous CD38 molecules on the outer side of the plasma membrane (Fig. 7C).

$R T-P C R$. RT-PCR analysis revealed the occurrence in tonsil tissue of specific transcripts for neurotrophins (NGF, BDNF, NT-3) and their high-affinity receptors (TrkA, TrkB, TrkC) (Fig. 8). Furthermore, in line with our immunohistochemical results, mRNA for p75 was undetectable (Fig. 8).

\section{Discussion}

Neurotrophins (NTs) are neurotrophic signaling polypeptides which play physiological roles in the development, maintenance and regeneration of the sympathetic and sensory nervous system $(3,7)$. Moreover, NGF induces differentiation and decreases growth rate in a variety of neoplastic cells from neurogenic and non-neurogenic origin $(9,23-26)$. The present study describes the localization in human tonsil tissue of some neurotransmitters (SP, VIP, CGRP, ChAT, and nNOS), some NTs, such as NGF, BDNF, NT-3, and their high- and lowaffinity receptors (TrkA, TrkB, TrkC and p75), that usually mediate the neurotrophic actions in the central nervous system $(6,27)$.

The possible action of neurotrophins on lymphocytes was first reported by Dean et al (28), who observed that NGF 

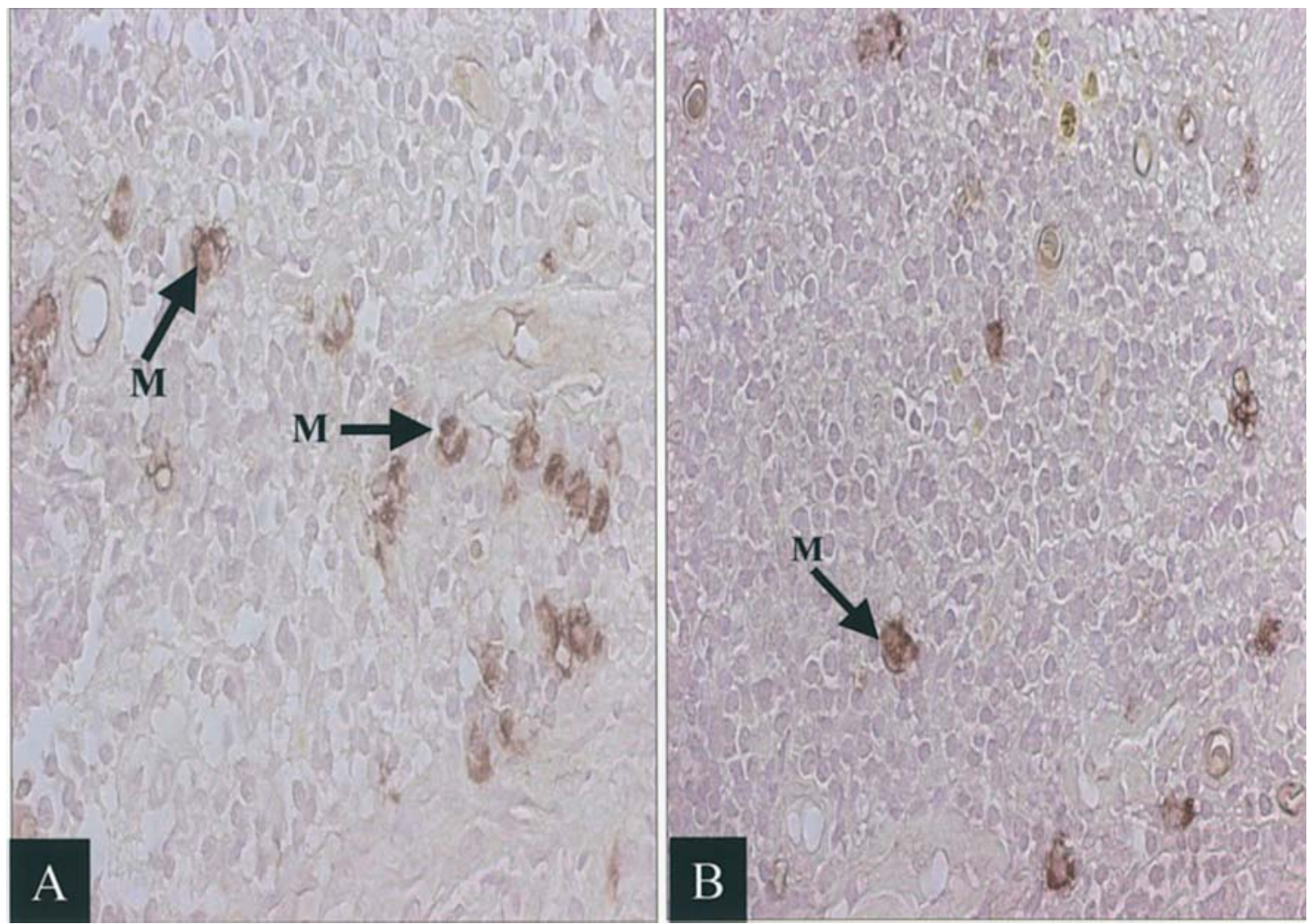

Figure 3. Human tonsil tissue: patient no. 2. Micrographs of NT-3 (A) and Trk-C (B) immunostaining. Strong immunoreactivity for NT-3 and its specific receptor TrkC is evident in macrophages $(\mathrm{M})$. Lymphocytes are slightly stained only in some patients.
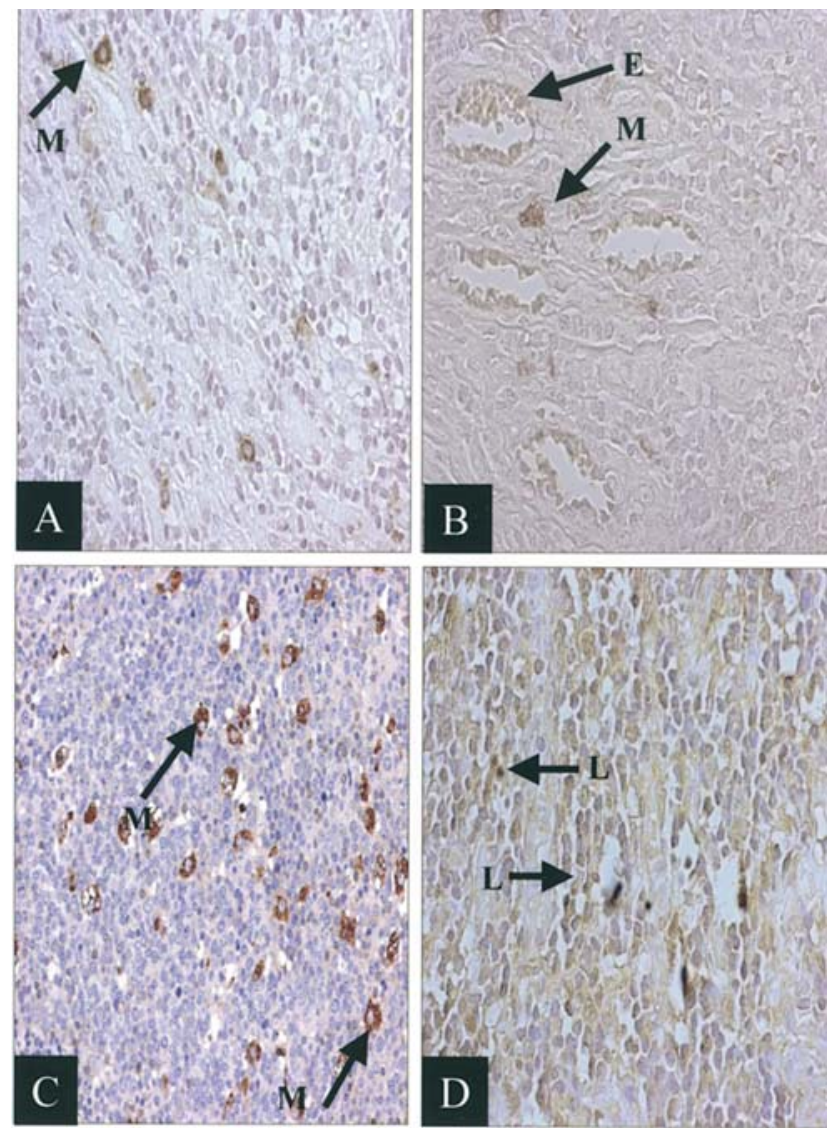

Figure 4. Human tonsil tissue: patient no. 2. Micrographs of SP (A), VIP (B), CGRP (C) and ChAT (D). Strong immunoreactivity for SP, VIP and CGRP is associated to macrophages (M), whereas ChAT immunostaining is strong in lymphocytes $(\mathrm{L})$.

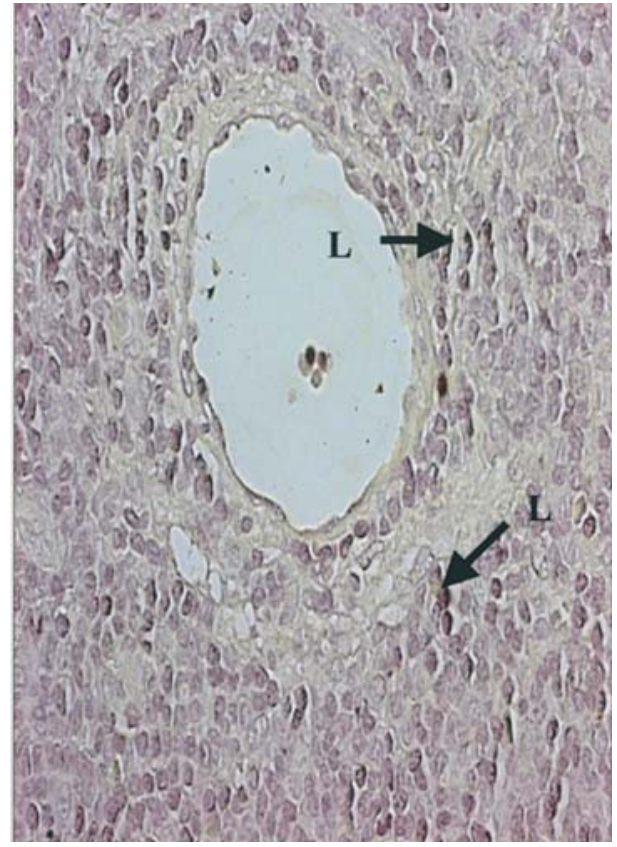

Figure 5. Human tonsil tissue: patient no. 3. Micrographs of nNOS immunostaining. Moderate immunoreactivity is evident in lymphocytes (L) and blood vessel endothelium. Macrophages are slightly stained.

increased the blastogenic response of mouse spleen cells. This observation suggested that lymphocytes (and perhaps other immunocompetent cells) expressed neurotrophin receptors. Further observations proved that these cells synthesize and release neurotrophins, leading to the hypothesis that there might be an autocrine and paracrine action of NTs 

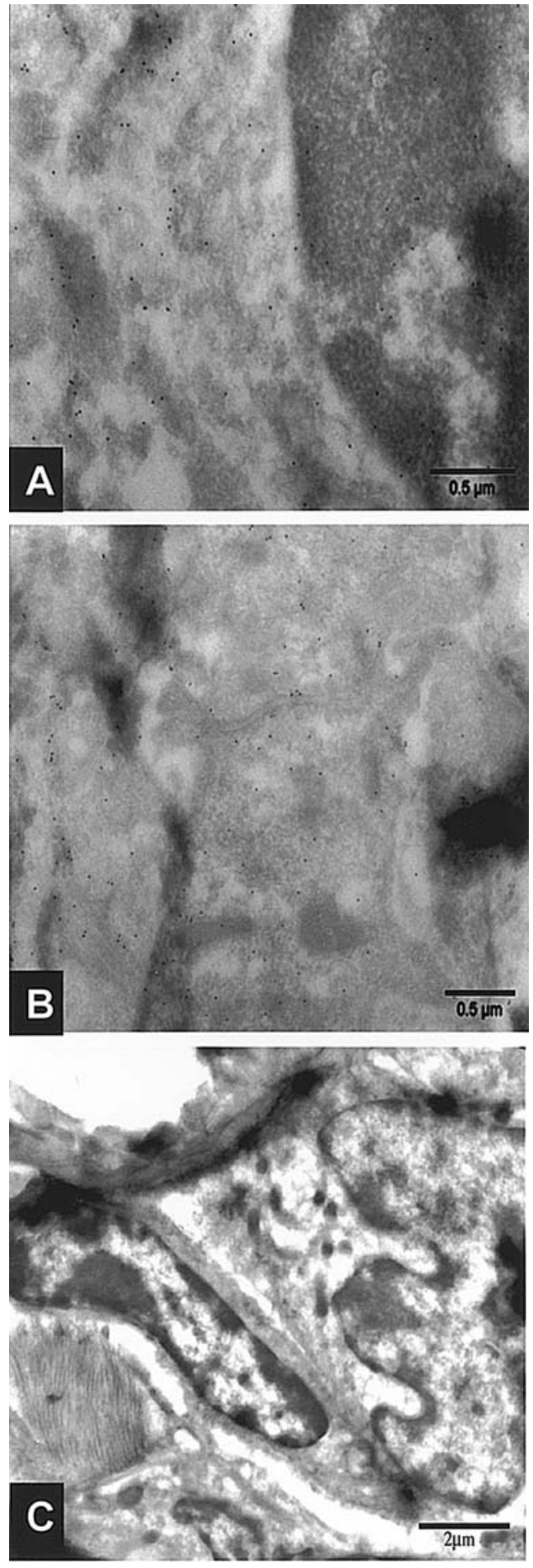

Figure 6. Transmission electron microscopy cryosections of human tonsil tissue. A-Macrophagic cell labelled with anti-NGF antibody. Numerous gold particles are randomly distributed inside the cytoplasm. B-Macrophagic cell labelled with anti-TrkA antibody. Clusters of gold particles are visible in the cytoplasm of both cells. C-Negative control cryosection showing that morphology of the different cell types appears to be well preserved.

on the same cells (29). Moreover, the most important and interesting result concerning the expression of both NTs and their receptors in lymphocytes is represented by the fact that this possibility depends on the cell activation $(30,31)$. In fact, expression of both NGF and TrkA is induced by mitogen activation in $\mathrm{CD}^{+} \mathrm{T}$ cells (32). Moreover, both $\mathrm{CD} 4^{+}$and $\mathrm{CD}^{+} \mathrm{T}$ cells produce $\mathrm{NGF}$, which is increased after
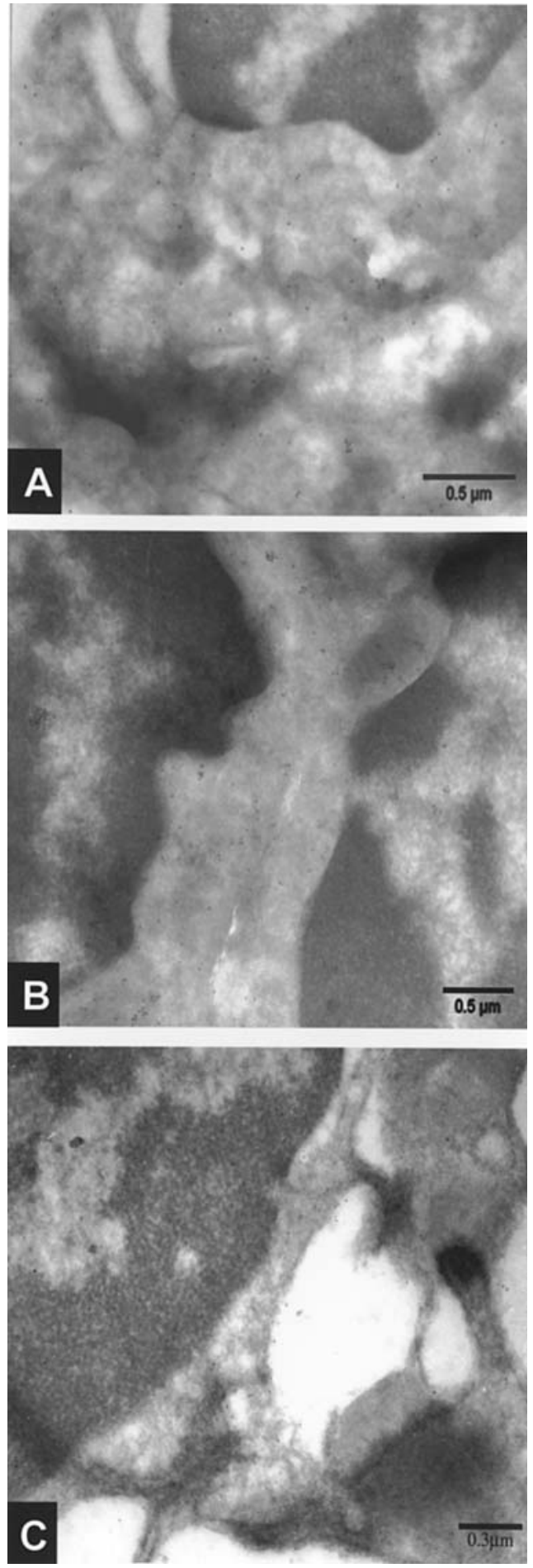

Figure 7. Transmission electron microscopy cryosections of human tonsil tissue. A-Lymphocyte labelled with anti-BDNF antibody. Numerous gold particles are evident inside the cytoplasm whereas the nucleus is completely negative. B- Lymphocyte labelled with anti-TrkB antibody. Numerour gold particles are observed inside the cytoplasmatic matrix and plasma membrane. C-Lymphocyte labelled with anti-CD38 antibody. The presence of numerous CD38 molecules on the cell surface demonstrates the lymphocytic nature of these cells.

antigenic stimulation in the Th2 subset (33). Furthermore other studies $(34,35)$ confirmed that unstimulated human CD4 ${ }^{+}$Th1 and Th2 cells (but not Th0 cells) express both NGF and TrkA, and Th1 cells express full-length TrkB and low levels of TrkC. $\mathrm{CD}^{+}$and $\mathrm{CD}^{+} \mathrm{T}$ cells transcribe also BDNF mRNA and produce bioactive BDNF, NT-3 and 


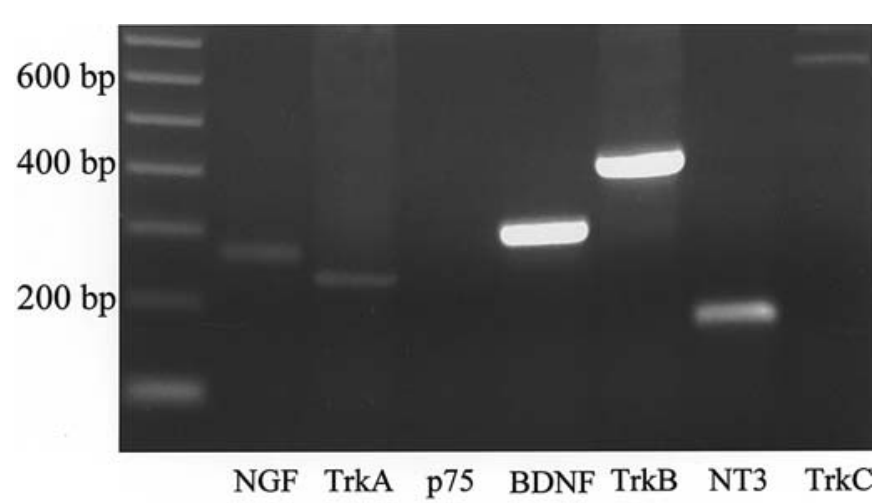

Figure 8. RT-PCR analysis of neurotrophins and related receptors in human tonsil tissue. All analysed NTs and high-affinity receptors are expressed in human palatine tonsils whereas mRNA for low-affinity receptor p75 is absent.

NT4/5 $(30,31,36)$. Otherwise, the expression of p75 NT by T cells remains controversial $(32,37)$. The expression of TrkA (38-40) and p75NT (41) in B cells has been reported. According to Schenone et al (42), B cells do not express mRNA for either p75NT or TrkA and, moreover, BDNF activates TrkB receptors on B cells. The occurrence of TrkB and TrkC on B cells has been previously confirmed $(35,40)$. Furthermore, it has been shown that B cells produce NGF and NT-3 $(33,35,39)$. In human palatine tonsils, p75 is exclusively present in follicular dendritic cells and in periarteriolar macrophages (43-46). Concerning TrkA, dendritic cells and interdigitated reticular cells have been found in cryptic tonsilar epithelium (44-46). Analogous results have been observed in bovine lymphoid organs $(47,48)$.

In the present study, a moderate to strong immunoreactivity for neurotransmitters, NTs and NT receptors was observed in tonsil tissue; in particular, NTs and their own high-affinity receptors were strongly expressed in macrophages and, to a lesser extent, in lymphocytes. Only immunoreactivity for TrkB was evident also in lymphocytes. The whole tissue does not show any expression of p75 in any of the analyzed patients and this is in line with the majority of reports available in the literature $(32,37)$. Specific immunoreactivity for NTs and NT receptors was also demonstrated within different layers of large, medium and small sized arteries and veins, according to a recent study of our group (49) performed in other mucosaeassociated lymphoid tissues. This evidence supports the role of these growth factors in the modulation of the immune functions in the mucosae-associated lymphoid tissues $(1,7,8,50-55)$. Electron microscopy immunolabelling confirmed the localization of NTs and their receptors, mainly in macrophages, as well as the strong expression of the TrkB receptor by lymphocytes. In line with our immunohistochemical analysis, RT-PCR experiments demonstrated the occurence of specific transcripts for NTs and their high-affinity receptors as well as the absence of the low-affinity NGF receptor, p75.

In the present study, the evidence of a moderate expression of NGF within the germinative centre is consistent with previous studies demonstrating that NGF was constitutively produced by B cells (39). Regarding this connection, NGF may be considered an autocrine survival factor for memory B lymphocytes, even though our study revealed it to be well expressed in macrophages. This last finding is in line with previous observations $(35,36,56-58)$ indicating that NGF, BDNF and NT-4/5 may be expressed by macrophages. Moreover, a recent very interesting observation (59) has demonstrated that both NGF and BDNF influence the cytokine expression pattern in peripheral blood mononuclear cells, as well as in antigen-specific $\mathrm{T}$ cells, modulating the production of interleukin-4, TGF- $\beta$, TNF- $\alpha$ and $\gamma$-interferon. It is already well known $(13,60)$ that NGF has an inflammatory role and its increase is directly related to inflammation, allergies and diseases of the immune system. NGF levels are also increased in asthma and in other allergic diseases (34,61-64). Moreover, systemic NGF administration increases histamine-induced bronchial hyperreactivity, probably via an intervention of tachykinins released by macrophages or mast cells (65). An altered regulation of NT production or NT receptor expression may be responsible for the control of the growth, differentiation and apoptosis of some kinds of nonneuronal tumours $(29,66)$, such as pancreatic ductal adenocarcinoma (67), melanoma (68), prostate cancer (69) and lung cancer (70).

In the present study, ChAT has been found to be expressed in the lymphocytes, but also in macrophages. SP, VIP and CGRP were well-expressed in macrophages, and a weak immunoreaction was detected in lymphatic cells and blood vessels. nNOS was only slightly expressed in all analyzed structures.

In conclusion, our data collectively suggest the existence of an extensive network of innervation in human tonsil lymphoid tissue, which may play a role in the regulation of some immune functions and in the modulation of complex interactions among different immune cellular subtypes in physiological as well as inflammatory conditions. Our data also corroborate previous studies suggesting that neurotransmitters and neurotrophins may mediate functional signals in lymphoid aggregates $(5,7,8-12)$, thus confirming an important role of growth factors in the complex regulation of immune functions (29). Regarding this connection, owing to their widespread expression in immune organs and immunocompetent cells, NTs are candidates for a prominent role in the regulation of immune and neuroimmune interactions.

\section{References}

1. Felten SY, Felten DL, Bellinger DL and Olschowka JA: Noradrenergic and peptidergic innervation of lymphoid organs. Chem Immunol 52: 25-48, 1992.

2. Lewin GR and Barde YA: Physiology of neurotrophins. Ann Rev Neurosci 9: 289-217, 1996.

3. Barbacid M: The Trk family of neurotrophin receptors. J Neuroimmunol 25: 1386-1403, 1994.

4. Kaplan DR and Miller FD: Signal transduction by the neurotrophin receptors. Curr Opin Cell Biol 9: 213-221, 1997.

5. Lomen HC and Shooter EM: Widespread neurotrophin receptor expression in the immune system and other non-neuronal rat tissue. J Neurochem 64: 1780-1789, 1995.

6. Lommatzsch M, Braun A, Mannsfeldt A, Botchkarev VA, Botchkareva NV, Paus R, Fischer A, Lewin GR and Renz H: Abundant production of brain-derived neurotrophic factor by adult visceral epithelia implications for paracrine and targetderived neurotrophic functions Am J Pathol 155: 1183-1193, 1999.

7. Snider WD: Functions of the neurotrophins during nervous system development: what the knockouts are teaching us. Cell 77: 627-638, 1994. 
8. Canning BJ, Reynolds SM, Anukwu LU, Kajekar R and Myers AC: Endogenous neurokinins facilitate synaptic transmission in guinea pig airway parasympathetic ganglia. Am J Physiol Regul Integr Comp Physiol 283: R320-R330, 2002

9. Djakiew D, Delsite R, Pflug B, Wrathall J, Lynch JH and Onoda M: Regulation of growth by a nerve growth factor-like protein which modulates paracrine interactions between a neoplastic epithelial cell line and stromal cells of the human prostate. Cancer Res 51: 3304-3310, 1991.

10. Varvella F, Colella G and Scala G: Innervation of the bronchial tree in cattle. Boll Soc Ital Biol Sper 57: 304-309, 1981.

11. Mutoh T, Bonham AC and Joad JP: Substance P in the nucleus of the solitary tract augments bronchopulmonary $\mathrm{C}$ fiber reflex output. Am J Physiol Regul Integr Comp Physiol 279: R1215-R1223, 2000

12. Schlosser RJ, Czaja JM, Yang B and McCaffrey TV: Signal transduction mechanisms in substance P-mediated ciliostimulation. Otolaryngol Head Neck Surg 113: 582-588, 1995.

13. Otten U and Gadient RA: Neurotrophins and cytokinesintermediaries between the immune and nervous systems. Int J Dev Neurosci 13: 147-151, 1995.

14. Tessarollo L: Pleiotropic functions of neurotrophins in development. Cytokine Growth Factor Rev 9: 125-137, 1998.

15. Aloe L, Simone MD and Properzi F: Nerve growth factor: a neurotrophin with activity on cells of the immune system. Microsc Res Tech 45: 285-291, 1999.

16. Aloe L: Nerve growth factor and neuroimmune responses: basic and clinical observations. Arch Physiol Biochem 109: 354-356, 2001.

17. Sariola $\mathrm{H}$ : The neurotrophic factors in non-neuronal tissues. Cell Mol Life Sci 58: 1061-1066, 2001.

18. Kannan Y, Stead RH, Goldsmith CH and Bienenstock J: Lymphoid tissues induce NGF-dependent and NGFindependent neurite outgrowth from rat superior cervical ganglia explants in culture. J Neurosci Res 37: 374-383, 1994.

19. Kannan Y, Bienenstock J, Ohta M, Stanisz AM and Stead RH: Nerve growth factor and cytokines mediate lymphoid tissueinduced neurite outgrowth from mouse superior cervical ganglia in vitro. J Immunol 157: 313-320, 1996.

20. Carlson SL, Albers KM, Beiting DJ, Parish M, Conner JM and Davis BM: NGF modulates sympathetic innervation of lymphoid tissues. J Neurosci 15: 5892-5899, 1995.

21. Carlson SL, Johnson S, Parrish ME and Cass WA: Development of immune hyperinnervation in NGF-transgenic mice. Exp Neurol 149: 209-220, 1998.

22. Tokuyasu KT: A technique for ultracryotomy of cell suspensions and tissues. J Cell Biol 57: 551-565, 1973.

23. Yaeger MJ, Koestner A, Marushige K and Marushige Y: The reverse transforming effects of nerve growth factor on five human neurogenic tumor cell lines: in vitro results. Acta Neuropathol 83: 72-80, 1991.

24. Oelmann E, Sreter L, Schuller I, Serve H, Koenigsmann M, Wiedenmann B, Oberberg D, Reufi B, Thiel E and Berdel WE: Nerve growth factor stimulates clonal growth of human lung cancer cell lines and a human glioblastoma cell line expressing high-affinity nerve growth factor binding sites involving tyrosine kinase signaling. Cancer Res 55: 2212-2219, 1995.

25. Pahlman S and Hoenher JC: Neurotrophin receptors, tumor progression and tumor maturation. Mol Med Today 2: 432-438, 1996.

26. Sala R, Viegi A, Rossi FM, Pizzorusso T, Bonanno G, Raiteri M and Maffei L: Nerve growth factor and brain derived neurotrophic factor increase neurotransmitter release in the rat visual cortex. Eur J Neurosci 10: 2185-2191, 1998.

27. Inoue N, Magari S and Sakanaka M: Distribution of peptidergic nerve fibers in rat bronchus-associated lymphoid tissue: light microscopic observations. Lymphology 23: 155-160, 1990.

28. Dean DH, Hiramoto RN and Ghanta VK: Modulation of immune response. A possible role for murine salivary epidermal and nerve growth factors. J Periodontol 58: 498-500, 1987.

29. Vega JA, Garcia-Suarez O, Hannestad J, Perez-Perez M and Germana A: Neurotrophins and the immune system. J Anat 203: $1-19,2003$

30. Kerschensteiner M, Gallmeier E, Behrens L, Leal VV, Misgeld T, Klinkert WE, Kolbeck R, Hoppe E, OropezaWekerle RL, Bartke I, Stadelmann C, Lassmann H, Wekerle H and Hohlfeld R: Activated human T cells, B cells, and monocytes produce brain-derived neurotrophic factor in vitro and in inflammatory brain lesions: a neuroprotective role of inflammation? J Exp Med 189: 865-870, 1999.
31. Moalem G, Gdalyahu A, Shani Y, Otten U, Lazarovici P, Cohen IR and Schwartz M: Production of neurotrophins by activated T cells: implications for neuroprotective autoimmunity. J Autoimmun 15: 331-345, 2000.

32. Ehrhard PB, Erb P, Graumann U and Otten U: Expression of nerve growth factor and nerve growth factor receptor tyrosine kinase Trk in activated CD4-positive T-cell clones. Proc Natl Acad Sci USA 90: 10984-10988, 1993

33. Santambrogio L, Benedetti M, Chao MV, Muzaffar R, Kulig K, Gabellini N and Hochwald G: Nerve growth factor production by lymphocytes. J Immunol 153: 4488-4495, 1994.

34. Lambiase A, Bracci-Laudiero L, Bonini S, Bonini S, Starace G, $\mathrm{D}^{\prime}$ Elios MM, De Carli M and Aloe L: Human CD4 ${ }^{+} \mathrm{T}$ cell clones produce and release nerve growth factor and express high-affinity nerve growth factor receptors. J Allergy Clin Immunol 100: 408-414, 1997

35. Besser M and Wank R: Cutting edge: clonally restricted production of the neurotrophins brain-derived neurotrophic factor and neurotrophin-3 mRNA by human immune cells and Th1/Th2-polarized expression of their receptors. J Immunol 162: 6303-6306, 1999 .

36. Braun A, Lommatzsch M, Mannsfeldt A, Neuhaus-Steinmetz U, Fischer A, Schnoy N, Lewin GR and Renz H: Cellular sources of enhanced brain-derived neurotrophic factor production in a mouse model of allergic inflammation. Am J Respir Cell Mol Biol 21: 537-546, 1999.

37. Kittur SD, Song L, Endo H and Adler WH: Nerve growth factor receptor gene expression in human peripheral blood lymphocytes in aging. J Neurosci Res 32: 444-448, 1992.

38. Melamed I, Kelleher CA, Franklin RA, Brodie C, Hempstead B, Kaplan D and Gelfand EW: Nerve growth factor signal transduction in human B lymphocytes is mediated by gp140Trk. Eur J Immunol 26: 1985-1992, 1996

39. Torcia M, Bracci-Laudiero L, Lucibello M, Nencioni L, Labardi D, Rubartelli A, Cozzolino F, Aloe L and Garaci E: Nerve growth factor is an autocrine survival factor for memory B lymphocytes. Cell 85: 345-356, 1996.

40. D'Onofrio M, de Grazia U, Morrone S, Cuomo L, Spinsanti P, Frati L, Gulino A and Ragona G: Expression of neurotrophin receptors in normal and malignant B lymphocytes. Eur Cytokine Netw 11: 283-291, 2000

41. Brodie C, Oshiba A, Renz H, Bradley K and Gelfand EW: Nerve growth-factor and anti-CD40 provide opposite signals for the production of $\mathrm{IgE}$ in interleukin-4-treated lymphocytes. Eur J Immunol 26: 171-178, 1996.

42. Schenone A, Gill JS, Zacharias DA and Windebank AJ: Expression of high- and low-affinity neurotrophin receptors on human transformed B lymphocytes. J Neuroimmunol 64: 141-149, 1996.

43. Pezzati P, Stanisz AM, Marshall JS, Bienenstock J and Stead RH: Expression of nerve growth factor receptor immunoreactivity on follicular dendritic cells from human mucosa associated lymphoid tissues. Immunology 76: 485-490, 1992.

44. Hannestad J, Levanti MB and Vega JA: Distribution of neurotrophin receptors in human palatine tonsils: an immunohistochemical study. J Neuroimmunol 58: 131-137, 1995

45. Garcia-Suarez O, Hannestad J, Esteban I, Martinez del Valle M, Naves FJ and Vega JA: Neurotrophin receptor-like protein immunoreactivity in human lymph nodes. Anat Rec 249: 226-232, 1997.

46. Labouyrie E, Parrens M, de Mascarel A, Bloch B and Merlio JP: Distribution of NGF receptors in normal and pathologic human lymphoid tissues. J Neuroimmunol 77: 161-173, 1997.

47. Levanti B, Hannestad J, Esteban I, Ciriaco E, Germana G and Vega JA: Neurotrophin receptor-like proteins in Peyer's patches. Anat Rec 249: 365-372, 1997.

48. Levanti MB, Germana A, Catania S, Germana GP, GaunaAnasco L, Vega JA and Ciriaco E: Neurotrophin receptor-like proteins in the bovine (Bos taurus) lymphoid organs, with special reference to thymus and spleen. Anat Histol Embryol 30: 193-198, 2001.

49. Ricci A, Greco S, Amenta F, Bronzetti E, Felici L, Rossodivita I, Sabbatini M and Mariotta S: Neurotrophins and neurotrophin receptors in human pulmonary arteries. J Vasc Res 37: 355-363, 2000.

50. Bronzetti E, Artico M, Lo Vasco VR, Felici LM, Bosco S, Magliulo G, Pompili E and Fumagalli L: Expression of neurotransmitters and neurotrophins in human adenoid tissue. Int J Mol Med 15: 921-928, 2005. 
51. Martling CR, Matran R, Alving K, Hokfelt T and Lundberg JM: Innervation of lower airways and neuropeptide effects on bronchial and vascular tone in the pig. Cell Tissue Res 260: 223-233, 1990.

52. Reinheimer T, Bernedo P, Klapproth H, Oelert H, Zeiske B, Racke K and Wessler I: Acetylcholine in isolated airways of the rat, guinea pig, and human: species differences in role of airway mucosa. Am J Physiol 270: L722-728, 1996.

53. Nohr D and Weihe E: The neuroimmune link in the bronchusassociated lymphoid tissue (BALT) of cat and rat: peptides and neural markers. Brain Behav Immun 5: 84-101, 1991.

54. Sonea IM, Bowker RM, Robinson NE and Broadstone RV: Substance $\mathrm{P}$ and calcitonin gene-related peptide-like immunoreactive nerve fibers in lungs from adult equids. Am $\mathbf{J}$ Vet Res 55: 1066-1074, 1994.

55. Busse W, Elias J, Sheppard D and Banks-Schlegel S: Airway remodelling and repair. Am J Respir Crit Care Med 160: 1035-1042, 1999.

56. Schober A, Huber K, Fey J and Unsicker K: Distinct populations of macrophages in the adult rat adrenal gland: a subpopulation with neurotrophin-4-like immunoreactivity. Cell Tissue Res 291: 365-373, 1998

57. Boven LA, Middel J, Portegies P, Verhoef J, Jansen GH and Nottet HS: Overexpression of nerve growth factor and basic fibroblast growth factor in AIDS dementia complex. J Neuroimmunol 97: 154-162, 1999.

58. Caroleo MC, Costa N, Bracci-Laudiero L and Aloe L: Human monocyte/macrophages activate by exposure to LPS overexpress NGF and NGF receptors. J Neuroimmunol 113: 193-201, 2001.

59. Bayas A, Kruse N, Moriabadi NF, Weber F, Hummel V, Wohleben G, Gold R, Toyka KV and Rieckmann P: Modulation of cytokine mRNA expression by brain-derived neurotrophic factor and nerve growth factor in human immune cells. Neurosci Lett 335: 155-158, 2003.

60. Stanisz AM and Stanisz JA: Nerve growth factor and neuroimmune interactions in inflammatory diseases. Ann NY Acad Sci 917: 268-272, 2000
61. Bonini S, Lambiase A, Bonini S, Angelucci F, Magrini L, Manni L and Aloe L: Circulating nerve growth factor levels are increased in humans with allergic diseases and asthma. Proc Natl Acad Sci USA 93: 10955-10960, 1996.

62. Sanico AM, Koliatsos VE, Stanisz AM, Bienenstock J and Togias A: Neural hyperresponsiveness and nerve growth factor in allergic rhinitis. Int Arch Allergy Immunol 118: 154-158, 1999.

63. Renz H: The role of neurotrophins in bronchial asthma. Eur J Pharmacol 429: 231-237, 2001.

64. de Vries A, Engels F, Henricks PA, Leusink-Muis T, Fischer A and Nijkamp FP: Antibodies directed against nerve growth factor inhibit the acute bronchoconstriction due to allergen challenge in guinea-pigs. Clin Exp Allergy 32: 325-328, 2002.

65. de Vries A, Dessing MC, Engels F, Henricks PA and Nijkamp FP: Nerve growth factor induces a neurokinin-1 receptor-mediated airway hyperresponsiveness in guinea pigs. Am J Respir Crit Care Med 159: 1541-1544, 1999.

66. Rubin JB and Segal RA: Growth, survival and migration: the Trk to cancer. Cancer Treat Res 115: 1-18, 2003.

67. Miknyoczki SJ, Lang D, Huang L, Klein-Szanto AJ, Dionne CA and Ruggeri BA: Neurotrophins and Trk receptors in human pancreatic ductal adenocarcinoma: expression patterns and effects on in vitro invasive behavior. Int J Cancer 81: 417-427, 1999.

68. Innominato PF, Libbrecht L and van den Oord JJ: Expression of neurotrophins and their receptors in pigment cell lesions of the skin. J Pathol 194: 95-100, 2001

69. Satoh F, Mimata H, Nomura T, Fujita Y, Shin T, Sakamoto S, Hamada Y and Nomura Y: Autocrine expression of neurotrophins and their receptors in prostate cancer. Int J Urol 8: S28-34, 2001.

70. Ricci A, Greco S, Mariotta S, Felici L, Bronzetti E, Cavazzana A, Cardillo G, Amenta F, Bisetti A and Barbolini G: Neurotrophins and neurotrophin receptors in human lung cancer. Am J Respir Cell Mol Biol 25: 439-446, 2001. 